\title{
研究速報
}

\section{フィールド周波数を可変する固体テレビカメラ の走査方式}

\author{
正会員 三 村 到 ${ }^{\dagger}$, 正会員 佐 藤 和 弘 $^{\dagger \dagger}$
}

あらまし 固体テレビカメラの $S / N$ 改善を目的とした新しい走查方式を検討した．本方式は， 被写体の動きを検出し, 動きに応じて動解像度と感度を最適化する方式である. 今回, 動き検出用 の走査と, 蓄積時間を可変し感度を調節する走查を 1 枚の固体撮像素子に行わせる方式を考案し た. MOS 型撮像素子を用いた実験カメラにより素子の動作を確認し, 本カメラの可能性を示し た.

\section{1. ま え がき}

固体テレビカメラの感度向上を目的に, 新しい走査 方式を提案する. 現在のテレビカメラは毎秒 60 フィ ールドの走查を行っている，そのため, フィールド周 波数で定まる信号蓄積時間により感度が制約されてい る.この問題を解決するひとつのアプローチとして, フィールド周波数を可変する新しい走査方式を検討し た。

\section{2. フィールド周波数可変走査方式}

提案する走査方式では, 被写体の明るさ, 動きを検 出してフィールド周波数を可変する. 感度が不足する 低照度被写体を撮影する時は, フィールド周波数を通 常よりも低くし蓄積時間を長くする。 また, 低照度で あっても動きを伴う被写体に対しては, 蓄積動作を停 止し動解像度の低下を防止する . 上記動作を可能とす るには, 被写体の明るさ, 動きを検出する必要があ る、特に動きを検出するには一定の周波数で動作する 撮像素子が別途必要となる.

今回, 上記 2 つ走查, すなわち蓄積時間可変の走 査, 動き検出のための固定周波数の走查を 1 つの撮像 素子で実現する方法を考案した。本方式は，MOS 型 撮像素子の走查の柔軟性が高いことを利用し, 偶数行

\footnotetext{
$\dagger$ 株式会社日立製作所 中央研究所

†† 日立マイクロコンピュータエンジニアリング

"New Scanning Method with Variable Field Frequency for Solid State TV Camera" by Itaru Mimura (Central Reserch Lab., Hitachi Ltd., Tokyo) and Kazuhiro Sato (Hitachi Micro Computer Engineering Ltd., Gunma)
}

に可変蓄積時間の走査を，また奇数行に動き，明るさ 検出の固定蓄積時間の走査を行わせる新しい方式であ る。

\section{3. カメラの構成および動作}

本カメラに利用可能な MOS 形撮像素子の構成を図 1 に示す。この素子は「2 行同時読出し」の構造になっ ている ${ }^{1)}$. 奇数行画素の可変走査は, 水平走査線選択 スイッチ G 1 の開閉制御で実現できる.信号を蓄積 するフィールドでは, スイッチ G 1 を開くことで垂 直走查パルスの供給を停止し, フィールド単位に信号 蓄積時間を長くする。なお信号を読出す場合は，固定 蓄積時間の走査と同じく1フィールド期間内に全画素 の信号を読出す.

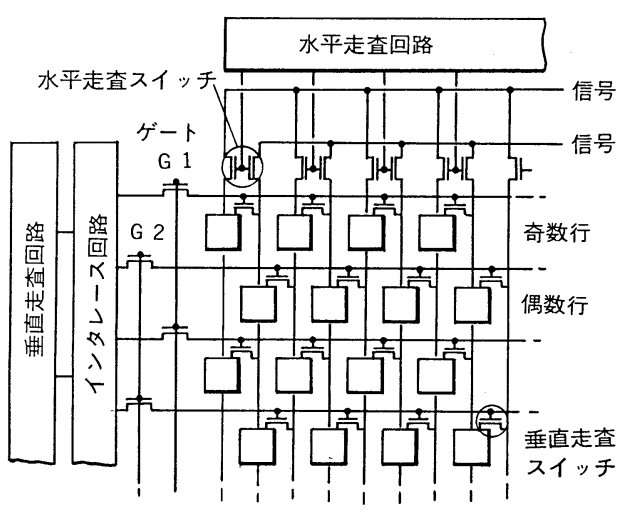

図 1 MOS 型撮像素子の構成 Configuration of MOS imager. 


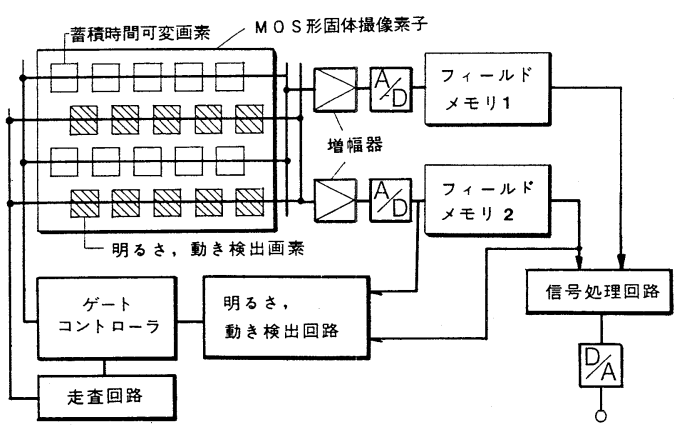

図 2 可変フィールド周波数カメラのブロック図 Schematic diagram of variable field frequency TV camera.

図 2 に本テレビカメラのブロック図を示す.ゲート コントローラはスイッチ G 1 を制御する，走査パル スによりアクセスされた画素の信号は，2 本の信号線 により独立に読出し, 増幅, ディジタル化した後, フ イールドメモリー $1 ， 2$ 亿格納する. 被写体の明るさ は固定周波数で走査する偶数行画素の平均信号レベル から検出する．また，動きはフィールド間差分から検 出する方式とし，フィールドメモリー 2 と動き検出回 路を用いる. 明るさ, 動き検出回路は検出結果から奇 数行画素のフィールド周波数を定める. 低照度では蓄 積時間を長く，また動被写体では短くする。フィール ドメモリー 1 は，こま落しで読出された奇数行画素の 信号を 60 フィールド/秒の信号に変換するために用い る。

\section{4. 動作確認実験}

上記テレビカメラを試作し動作確認実験を行った． なお, 今回の試作カメラは, 動き適応動作を行わず, 蓄積時間はマニュアル，あるいは明るさによって制御 した。

試作カメラにおいて, 奇数行画素のフィールド周波 数を $3.75 \sim 60 \mathrm{~Hz}$ に変化させたところ，いずれの周 波数でも撮像素子は良好に動作した。一例として，写 真 1 に奇数行画素を $3.75 \mathrm{~Hz}$, 偶数行画素を $60 \mathrm{~Hz}$ で 走査した時の撮像例を示す. 被写体としてメトロノー ムに白紙を貼ったものを用いた。動きを分かりやすく するため, 右側の背景を暗くしてある. 写真 1 の撮像 例は, フィールドメモリー1, およびフィールドメモ リー2 から奇, 偶数行の信号を読出して加算表示した ものである. なおインタレース走査は, 奇, 偶数フィ ールドで加算する行の組合せを変える 2 行同時読出し インタレース方式により実現した ${ }^{1)} .60 \mathrm{~Hz}$ の走查に

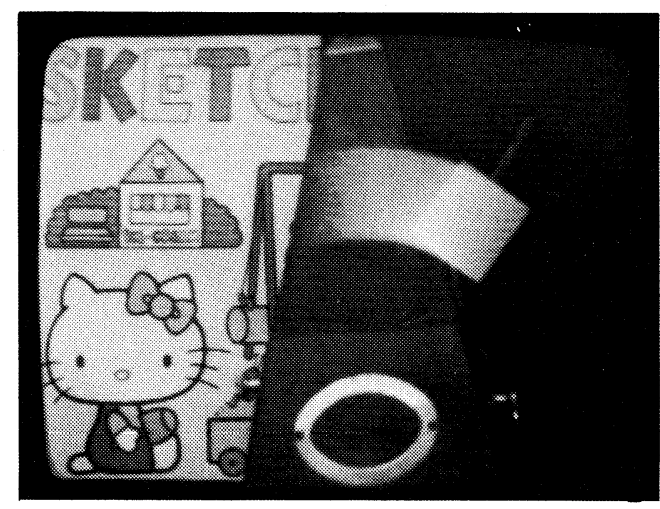

写真 1 撮像例 (奇数行: $3.75 \mathrm{~Hz}$, 偶数行: $60 \mathrm{~Hz}$ ) Picture with 2-field frequency.

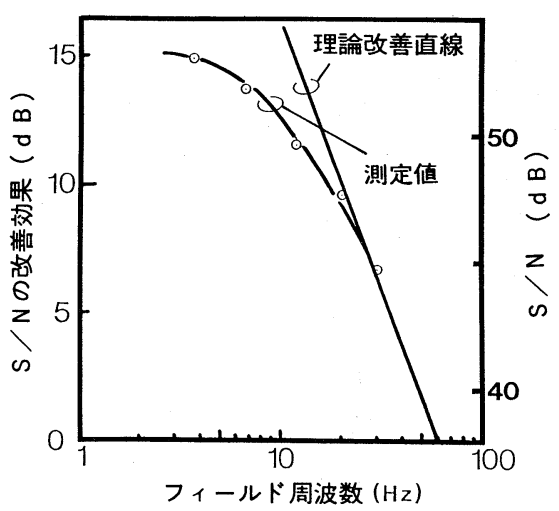

図 $3 S / N$ の改善効果

Improvement on signal to noise ratio.

よりブレなく撮影された像と, $3.75 \mathrm{~Hz}$ の走査により 蓄積期間内に像が移動した量のブレを含んだ像が同時 に再生されている. 写真 1 から撮像素子の偶, 奇数行 が独立した周波数で走査されていることがわかる.

図 3 にフィールド周波数を可変した時の偶数行画素 の $S / N$ 改善効果を示す. 改善効果 $0 \mathrm{~dB}$ は $S / N=38$ $\mathrm{dB}$ に対応させた. 偶数行画素において, フィールド 周波数が低いほど（蓄積時間が長いほど）， $S / N$ が改 善できることを確認した. 改善効果は理論上直線にな るが, 低周波数領域では実測值と差が生じている。こ の原因は量子化雑音, ディジタル系の飛び込み雑音, 後段回路の雑音の影響と考元られる.

明るさに応じてフィールド周波数を制御したとこ ろ, 低照度時においても奇数行画素からは $S / N$ の高 い信号が得られた。 また, 偶数行画素からは明るさ, 動き検出が可能な 60 フィールド/秒の信号が得られ た。 


\section{5.むす び}

固体テレビカメラの感度と動解像度の最適化を図る 方式として, 被写体の明るさ, 動きに応じてフィール ド周波数を可変する走查方式を検討した，今回, 動き 検出, 感度調節機能を持った 2 組の走査を 1 枚の MOS 型撮像素子に行わせた。試作カメラにより素子 の動作および蓄積可変による $S / N$ 改善を確認した。 これにより本カメラの可能性を示した。

今後, 偶数行画素からの動き検出, 動きに応じた信 号合成処理等の検討を進める予定である.

(昭和 63 年 5 月 11 日受付, 昭和 63 年 5 月 25 日再受付)
〔参 考 文 献〕

1）高橋活か：“補間画素配置を用いた高解像度 MOS 形固体撮 像素子”, テレビ誌, 37, 10（1983）

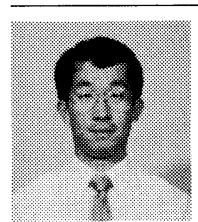

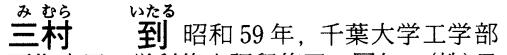
画像応用工学科修士課程修了. 同年, (株) 日 立製作所中央研究所に入所. 固体テレビカメ ラの研究に従事. 正会員.

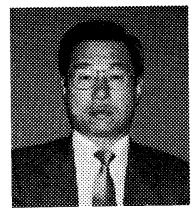

佐籐架和弘 昭和 39 年, 早稲田大学第 1 理工学部卒業. 日本コロムビア(株)から 47 年, (株) 日立製作所中央研究所に転じ, 撮像 方式, 固体撮像素子の研究侸事. 61 年よ り，日立マイクロコンピュータエンジニアリ ング(株)で，アナログIC の開発を担当. 正 会員. 